Docent dr Vojislav Batinić,

dipl. inž.

Vojna akademija,
Beograd
ODREĐIVANJE SOPSTVENIH UČESTANOSTI I OBLIKA OSCILOVANJA DELOVA PLANETARNOG PRENOSNIKA PRIMENOM METODE KONAČNIH ELEMENATA

UDC: 621.83

Rezime:

U radu je prikazan metodološki pristup određivanju sopstvenih učestanosti $i$ vibracionih modova delova planetarnog prenosnika korišćenjem metode konačnih elemenata. Modalnom analizom ostvarenom primenom metode konačnih elemenata, po pravilu, dobija se veliki broj modalnih oblika (frekvencija) sopstvenog oscilovanja. U realnim uslovima pobuđuju se samo neki od njih. Glavni cilj ovog rada jeste određivanje sopstvenih učestanosti da bi se sagledale konstrukcione mere i rešenja za sprečavanje modalnog oscilovanja.

Ključne reči: planetarni prenosnik, vibracije, sopstvene učestanosti, vibracioni modovi.

\title{
DETERMINING OF NATURAL FREQUENCIES AND FORMS OF OSCILLATION OF THE PARTS OF PLANETARY GEAR TRAINS USING FINITE ELEMENT METHOD
}

\section{Summary:}

This paper presents methodological approach to calculation of natural frequencies and modal shapes by using of finite elements metod. Modal anaysis realised by application of finite elements method, results by the rule, in a large number of modal shapes (frequencies) of natural oscillation. In real conditions only some of them are excited. The main purpose of this paper is calculation of natural frequencies that we can recognize design effort and solutions for hindering of modal oscillation.

Key words: planetary gear train, vibrations, natural frequencies, vibration modes.

\section{Uvod}

Vibracije mašinskih sistema su realna i nepovoljna pojava prisutna kod svih mašina, kao posledica dinamičkog stanja u kojem rade. U fazi projektovanja mašine projektant modeliranjem i konstruisanjem traži optimalni tehnički princip rada, pri čemu, pored drugih, rešava i problem vibracija.

Prenosnici koji se primenjuju u vazduhoplovstvu, automobilskoj industriji, brodskim, transportnim i drugim sistemima, a koriste planetarne setove, mogu imati neželjeno dinamičko ponašanje $s$ obzirom na buku i vibracije.

Vibracije i buku prenosnika snage pobuđuju sprege zubaca zupčanika, netačnost izrade elemenata, netačnost montaže, neravnomeran prenos snage po granama, obrtni momenti koji se dovode i odvode preko prenosnika $\mathrm{i}$ dr. Intenzitet i frekvencija pobude zavise od parametara ozubljenja, opterećenja i tačnosti geometrije. Pobuda se ostvaruje promenom deformacija zubaca u sprezi i stvaranjem inercijalnih sila, kao i dejstvom sila sudara zubaca pri ulaženju u spregu. Habanje 
i druga oštećenja, u toku rada, dovode do pojačavanja pobude. Dinamička opterećenja u setovima planetarnih prenosnika uslovljena su, osim navedenim uzrocima, još i neravnomernom raspodelom opterećenja na satelite, elastičnim deformacijama nosača satelita, vezivanjem centralnog sunčanog zupčanika i dr.

Za pravilnu ocenu dinamičkog ponašanja zupčastih prenosnika presudan uticaj ima poznavanje sopstvenih učestanosti i sopstvenih oblika oscilovanja. U radu je pokazan jedan primer rešenja kod nekoliko delova planetarnog prenosnika. Određivanje sopstvenih učestanosti izvršeno je primenom kompjuterskog paketa programa CATIA.

\section{O metodi konačnih elemenata}

Metoda konačnih elemenata (MKE) savremena je numerička metoda koja nalazi sve veću primenu u projektovanju i proračunima mašinskih delova $i$ konstrukcija uz primenu računara. Za razliku od drugih numeričkih metoda koje se zasnivaju na matematičkoj diskretizaciji jednačina graničnih problema, MKE se zasniva na fizičkoj diskretizaciji razmatranog kontinuuma delova konačnih dimenzija i jednostavnog oblika koji se nazivaju konačni elementi.

U fizičkom smislu, primenom MKE proučavano deformabilno telo, tj. kontinuum sa beskonačno mnogo stepeni slobode zamenjuje se diskretnim modelom međusobno povezanih konačnih elemenata sa konačnim brojem stepeni slobode kretanja. Matematički gledano, umesto sistema diferencijalnih jednačina koje definišu stanje ravnoteže celokupnog modela, primenom MKE dobija se sistem običnih algebarskih jednačina.
Pri diskretizaciji kontinuuma može se koristiti jedan tip konačnih elemenata ili kombinacija više tipova, kada se mora voditi računa o njihovom slaganju. Svi konačni elementi povezani su zajedničkim čvorovima, tako da čine prvobitnu konstrukciju. Usled postojanja velike raznolikosti problema, konstruktivnih oblika, geometrijskih veličina i uticaja kod mašinskih konstrukcija, do danas je razvijen veliki broj tipova (vrsta) konačnih elemenata, koji se razlikuju međusobno po obliku i po funkcijama oblika, odnosno interpolacionim funkcijama kojima se aproksimira polje promenljivih u konačnom elementu. Pri tome se, kao specijalna vrsta, izdvajaju izoparametarski konačni elementi, kod kojih se koriste isti čvorovi $\mathrm{i}$ iste interpolacione funkcije za aproksimaciju geometrije elementa i osnovnih nepoznatih u polju konačnog elementa, kao i kontaktni (,gap“) elementi koji se koriste pri modeliranju kontaktnih uslova kojih, takođe, ima više tipova, u zavisnosti od načina simuliranja kontakta.

Pri proučavanju nekog deformabilnog tela metodom konačnih elemenata, osnovni zadatak je izbor diskretnog modela koji najbolje aproksimira stanje deformacije i napona i granične uslove. Izbor diskretnog modela sastoji se u izboru tipa konačnog elementa koji se koristi (jedan ili više različitih), izboru njihovih posebnih osobina (ako postoje) i u izboru gustine mreže konačnih elemenata. Praktično, ne postoji egzaktni kriterijum za izbor najboljeg diskretnog modela koji obezbeđuje najveću tačnost pri rešavanju tačno definisanog zadatka. Zato je, pored poznavanja teorije konačnih elemenata, potrebno i široko inženjersko iskustvo i kvalitativno poznavanje stanja napona i stanja deformacija kod razmatranog mašinskog dela ili konstrukcije. 
$\mathrm{Na}$ osnovu izabranog tipa konačnog elementa, svojstva materijala i drugih veličina projektovanog problema, $u$ metodi konačnih elemenata postavljaju se veze između osnovnih veličina i formira se osnovna jednačina konačnog elementa. Grupisanjem osnovnih jednačina dobija se jednačina konstrukcije koja daje sistem linearnih jednačina za izračunavanje nepoznatih veličina.

Metoda konačnih elemenata zasniva se na postavkama mehanike kontinuuma (mehanike neprekidnih sredina). Osnovne postavke mehanike kontinuuma su opštepoznate i mogu se naći u različitoj literaturi. Ovde će se ukratko dati formulacija osnovnih jednačina MKE, opis korišćenih elemenata i postupak modeliranja kontaktnih uslova.

Osnovne jednačine metode konačnih elemenata

Za prikaz osnovnih jednačina u metodi konačnih elemenata koriste se varijacione metode. U zavisnosti od primenjene varijacione metode razlikuju se tri osnovna vida metode konačnih elemenata: metoda pomeranja ili metoda deformacije, metoda sila i mešovita metoda.

U metodi pomeranja ili metodi deformacija koristi se princip o minimumu potencijalne energije. Ova metoda konačnih elemenata primenjuje se kada su pomeranja ili deformacije osnovne nepoznate u čvornim tačkama mreže konačnih elemenata. Metoda sila zasnovana je na principu o minimumu komplementarne energije $i$ koristi se kada su statičke veličine (unutrašnje sile, komponente napona i sl.) usvojene za osnovne nepoznate. $\mathrm{Za}$ mešovitu metodu konačnih elemenata, koja se koristi kada se kao osnovne nepoznate javljaju delimično kinematičke, a delimično statičke veličine, primenjuje se Reissnerov varijacioni princip. Ovde će se detaljnije razmatrati metoda deformacije koja je korišćena u okviru numeričkog eksperimenta.

Osnovni zadatak u metodi deformacije predstavlja određivanje funkcija pomeranja, odnosno određivanje vrednosti pomeranja čvornih tačaka mreže konačnih elemenata. Kada je konstrukcija podeljena na konačne elemente međusobno povezane zajedničkim čvornim tačkama, pomeranja u bilo kojoj tački jednog konačnog elementa mogu da se odrede u funkciji pomeranja čvorova elemenata. Pri tome se usvaja da su pomeranja, deformacije i naponi neprekidne funkcije koordinata tačaka elemenata. Vektor pomeranja tačke jednog konačnog elementa, čije su komponente takođe neprekidne funkcije koordinata, ima oblik:

$\{s\}=\left\{\begin{array}{l}u \\ v \\ w\end{array}\right\}=\left\{\begin{array}{l}f_{1}(x, y, z) \\ f_{2}(x, y, z) \\ f_{3}(x, y, z)\end{array}\right\}$

Prema tome, problem se svodi na određivanje funkcija $f_{1}, f_{2} i_{3}$, tako da zadovolje ravnotežne i konturne uslove problema, odnosno na određivanje vektora osnovnih parametara pomeranja jednog konačnog elementa $\{S\}$ :

$\{S\}=\left\{\begin{array}{c}\{S\}_{1} \\ \{S\}_{2} \\ \{S\}_{3} \\ \vdots \\ \{S\}_{K}\end{array}\right\}$ 
pri čemu su $\{S\}_{\mathrm{k}}=\left\{\begin{array}{c}\mathrm{U} \\ \mathrm{V} \\ \mathrm{W}\end{array}\right\}_{\mathrm{k}}, \mathrm{k}=1,2, \ldots, \mathrm{K}-$ vektori pomeranja čvorova elemenata.

Vektor pomeranja neke tačke u polju razmatranog konačnog elementa, dat izrazom (2), može da se odredi na osnovu poznatog vektora $\{S\}$ i na osnovu usvojenih interpolacionih funkcija $b_{i}$ kojima se vrši linearna interpolacija pomeranja i koje, najčešće, predstavljaju polinome razvijene za ove namene, tj.:

$$
\{s\}=[N]\{S\}
$$

pri čemu je $[\mathrm{N}]$ - matrica interpolacionih funkcija.

$\mathrm{Na}$ sličan način, preko interpolacionih funkcija, postavlja se i veza između koordinata neke tačke u polju elementa i koordinata njegovih čvorova.

Matrice tenzora deformacije $\{\varepsilon\}$ i tenzora napona $\{\sigma\}$, u funkciji od vektora čvornih pomeranja $\{S\}$ posmatranog konačnog elementa, izračunavaju se na osnovu izraza:

$$
\{\varepsilon\}=[d]\{s\}=[d][N]\{S\}=[p]\{S\}
$$

i izraza:

$$
\{\sigma\}=[D]\{\varepsilon\}+\left\{\sigma^{t}\right\}=[D][p]\{S\}+\left\{\sigma^{t}\right\}(5)
$$

pri čemu je:

$[p]=[d][N]$,

[d]- diferencijalni operator,
[D] - matrica krutosti definisana u teoriji elastičnosti,

[N]- interpolaciona matrica,

$\left\{\sigma^{\mathrm{t}}\right\}$ - matrica tenzora napona od temperaturskih naprezanja.

\section{Osnovna jednačina konačnog elementa i ukupne strukture}

Za određivanje vektora čvornih pomeranja jednog konačnog elementa $\{S\}$ koristi se princip virtualnog rada, koji je prikazan u obliku:

$(\delta u)\{F\}=(\delta \varepsilon)\{\sigma\} d V$

pri čemu je $\{F\}$ - vektor spoljašnjih sila u čvorovima elementa.

Postavljanjem jednačina za virtualni rad ovih spoljašnjih sila i virtualni deformacioni rad, odnosno virtualni elastični potencijal unutrašnjih sila konačnog elementa i izjednačavanjem ova dva virtualna rada, dobija se jednačina za određivanje vektora $\{F\}$ :

$$
\{F\}=\int_{V}[p]^{T}[D][p]\{\} d V+\int_{V}[p]^{T}\left\{\sigma^{t}\right\} d V
$$

Ako se uvedu oznake:

$$
\left[K^{e}\right]=\int_{V}[p]^{T}[D][p] d V \quad \text { i }
$$

$\left\{F^{t}\right\}=\int_{V}[p]^{T}\left\{\sigma^{t}\right\} d V$

izraz (7) transformiše se u oblik: 


$$
\{F\}=\left[K^{e}\right]\{S\}+\left\{F^{t}\right\}
$$

Kada se uticaji temperaturskih naprezanja zanemare dobija se veza između čvornih pomeranja i čvornih sila, koja je u MKE poznata kao osnovna jednačina konačnog elementa:

$$
\{F\}=\left[K^{e}\right]\{S\}
$$

$\mathrm{U}$ ovim izrazima matrica $\left[\mathrm{K}^{\mathrm{e}}\right]$ predstavlja matricu krutosti konačnog elementa, čiji elementi zavise od fizičkih karakteristika materijala, karakteristika izabranog tipa konačnog elementa i izabranih interpolacionih funkcija.

Sjedinjavanjem osnovnih jednačina, oblika (10), svih konačnih elemenata koji čine mrežu tela ili konstrukcije dobija se jednačina konstrukcije u obliku:

$$
\{F\}=[K]\{S\}
$$

pri čemu je:

$$
\{F\}=\left\{\begin{array}{c}
\left\{F^{(1)}\right\} \\
\left\{F^{(2)}\right\} \\
\vdots \\
\left\{F^{(n)}\right\}
\end{array}\right\} ; \quad\{S\}=\left\{\begin{array}{c}
\left\{S^{(1)}\right\} \\
\left\{S^{(2)}\right\} \\
\vdots \\
\left\{S^{(n)}\right\}
\end{array}\right\}
$$

$\mathrm{U}$ ovim vektorima $\mathrm{n}$ predstavlja ukupan broj čvorova konstrukcije, koji je jednak zbiru ukupnog broja čvorova u mreži konačnih elemenata i broja oslonaca konstrukcije. Broj elemenata svake podmatrice u vektorima (12) jednak je broju stepeni slobode kretanja čvorova konačnog elementa, pa vektori $\{F\}$ i $\{\mathrm{S}\}$ imaju $\mathrm{p} \times \mathrm{n}$ elemenata ( $\mathrm{p}-$ broj stepeni slobode kretanja, $\mathrm{n}$ - broj čvorova).

Matrica krutosti [K] sastavljena je od $n \times n$ podmatrica $K_{r s}$ i može se napisati u skraćenom obliku kao:

$[K]=\sum_{e} K_{i j}^{(e)}, i, j=1,2, \ldots, n ;(e)=1,2, \ldots, m$

Određena čvorna pomeranja su unapred poznata i određena osloncima konstrukcije. Poznata čvorna pomeranja predstavljaju granične uslove konstrukcije. Kada se ovi granični uslovi uvrste u jednačinu konstrukcije (11) određeni broj jednačina se eliminiše, čime se smanjuje ukupan broj stepeni slobode sistema.

Spoljašnje sile koje opterećuju konstrukciju unose se u jednačinu konstrukcije preko komponenata sila u pravcima osa koordinatnog sistema u čvornim tačkama.

\section{Osnovna dinamička jednačina konačnog elementa i ukupne strukture}

U dinamičkim uslovima opterećenja, tj. kada je vektor čvornih sila za bilo koji konačni element (e) vremenska funkcija, na sam konačni element deluju još inercijalne sile i sile prigušenja.

Specifična inercijalna sila daje se preko

$-\rho \frac{\partial^{2}}{\partial t^{2}}\{s\}$ 
pri čemu su:

$\{\mathrm{s}\}$ - funkcija pomeranja (3), koja sada zavisi i od vremenske koord. t, i

$\rho$ - gustina ili masa jedinice zapremine konačnog elementa.

Specifična sila prigušenja, u slučaju viskoznog trenja je:

$-\beta \frac{\partial}{\partial t}\{s\}$

pri čemu je $\beta$ - koeficijent proporcionalnosti.

Ako se izjednače radovi spoljašnjih i unutrašnjih sila pri virtualnom pomeranju čvorova dobija se:

$$
\begin{aligned}
& \left(d\{S\}^{(e)}\right)^{T}\{F(t)\}^{(e)}=\int_{V}(d\{s\})^{T} \rho \frac{\partial}{\partial t^{2}}\{s\} d V- \\
& -\int_{V}(d\{s\})^{T} \beta \frac{\partial}{\partial t^{2}}\{s\} d V-\int_{V}(d\{\varepsilon\})^{T}\{\sigma\} d V
\end{aligned}
$$

pri čemu su: $\int_{\mathrm{V}}(\mathrm{d}\{\mathrm{s}\})^{\mathrm{T}} \rho \frac{\partial}{\partial \mathrm{t}^{2}}\{\mathrm{~s}\} \mathrm{dV}-\mathrm{rad}$ inercijalnih sila, $\int_{\mathrm{V}}(\mathrm{d}\{\mathrm{s}\})^{\mathrm{T}} \beta \frac{\partial}{\partial \mathrm{t}^{2}}\{\mathrm{~s}\} \mathrm{dV}-$ rad sila prigušenja, i $\int_{\mathrm{V}}(\mathrm{d}\{\varepsilon\})^{\mathrm{T}}\{\sigma\} \mathrm{dV}-$ specifični unutrašnji rad.

Sređivanjem jednačine (15) dobija se osnovna dinamička jednačina konačnog elementa:

$$
\begin{aligned}
& {[m]^{(e)} \frac{\partial}{\partial t^{2}}\{S\}^{(e)}+[b]^{(e)} \frac{\partial}{\partial t^{2}}\{S\}^{(e)}+} \\
& +[k]^{(e)}\{S\}^{(e)}=\{F(t)\}^{(e)}
\end{aligned}
$$

pri čemu su:

$[\mathrm{m}]^{(\mathrm{e})}=\int_{\mathrm{V}}[\mathrm{N}]^{\mathrm{T}} \rho[\mathrm{N}] \mathrm{dV}-$ matrica inercije

konačnog elementa, i

$[\mathrm{b}]^{(\mathrm{e})}=\int_{\mathrm{V}}[\mathrm{N}]^{\mathrm{T}} \beta[\mathrm{N}] \mathrm{dV}-$ matrica prigušenja konačnog elementa.

Šema sastavljanja ukupne inercione matrice i matrice prigušenja ista je kao i za ukupnu matricu krutosti, tj.:

$[M]=\sum_{(e)}\left[m_{i j}\right]^{(e)},[B]=\sum_{(e)}\left[b_{i j}\right]^{(e)}$

Osnovna dinamička jednačina za ukupnu strukturu diskretizovanu konačnim elementima je:

$[M]\{\ddot{S}\}+[B]\{\dot{S}\}+[K]\{S\}=\{F(t)\}$

pri čemu su:

$\{\ddot{\mathrm{S}}\}=\frac{\partial}{\partial \mathrm{t}^{2}}\{\mathrm{~S}\}, \quad\{\dot{\mathrm{S}}\}=\frac{\partial}{\partial \mathrm{t}}\{\mathrm{S}\}-$ vektori ubrzanja i brzina čvornih tačaka strukture.

\section{Određivanje sopstvenih učestanosti delova planetarnog seta}

Za rad planetarnih prenosnika bitne su sopstvene učestanosti ukupne strukture $\mathrm{i}$ isto tako sopstvene učestanosti pojedinih delova prenosnika. Ovde su objekti za analizu sopstvenih učestanosti delovi planetarnog seta, i to: nosač satelita, satelit i venačni zupčanik. 
Prostorni modeli delova planetarnog seta se diskretizuju korišćenjem 3D-tetraedalnih četvoročvornih konačnih elemenata sa 12 stepeni slobode (po tri translacije u svakom čvoru). Na slici 1 prikazan je prostorni model nosača satelita, diskretizovan konačnim elementima.

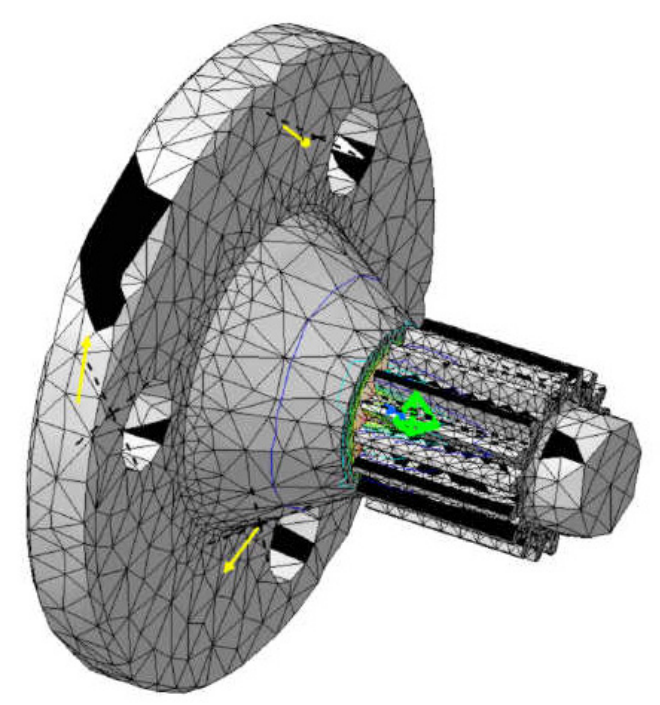

Sl. 1 -Nosač satelita diskretizovan konačnim elementima

Određivanje sopstvenih učestanosti izvršeno je primenom kompjuterskog paket programa CATIA. Pre određivanja učestanosti potrebno je izvršiti statičku analizu, tj. odrediti napone i deformacije za radno opterećenje nosača satelita. Pri tome su realne veze aproksimirane određenim „surface slider“ elementima. Nakon toga pobuda je izvršena pomoću „belog šuma“" koji obuhvata širok spektar frekvencija upravo zato da bi mogao da pobudi sve sopstvene frekvencije nosača satelita.
$\mathrm{Na}$ osnovu pobudnog spektra frekvencija izračunat je neki konačan broj sopstvenih učestanosti nosača satelita, a za analizu je uzeto prvih deset, čijim uspostavljanjem se bitnije utiče na dinamičko ponašanje sistema ili tela. Sopstvene učestanosti prikazane su u tabeli 1.

Tabela 1

\begin{tabular}{|c|c|c|c|c|c|c|c|c|c|c|}
\hline & $\begin{array}{c}\text { Mod } \\
1\end{array}$ & $\begin{array}{c}\text { Mod } \\
2\end{array}$ & $\begin{array}{c}\text { Mod } \\
3\end{array}$ & $\begin{array}{c}\text { Mod } \\
4\end{array}$ & $\begin{array}{c}\text { Mod } \\
5\end{array}$ & $\begin{array}{c}\text { Mod } \\
6\end{array}$ & $\begin{array}{c}\text { Mod } \\
7\end{array}$ & $\begin{array}{c}\text { Mod } \\
8\end{array}$ & $\begin{array}{c}\text { Mod } \\
9\end{array}$ & $\begin{array}{c}\text { Mod } \\
10\end{array}$ \\
\hline$\Omega / \mathrm{Hz}$ & 442 & 6664 & 6853 & 6942 & 8661 & 8691 & 9465 & 11927 & 12190 & 13707 \\
\hline
\end{tabular}

Svakoj sopstvenoj učestanosti odgovara sopstveni vektor, odnosno oblik oscilovanja, koji predstavlja kombinaciju pomeranja čvornih tačaka konačnih elemenata $u$ funkciji njihovih mogućih pomeranja. Na slikama 2 do 5 prikazani su oblici oscilovanja nosača satelita za pripadajuće im frekvencije.

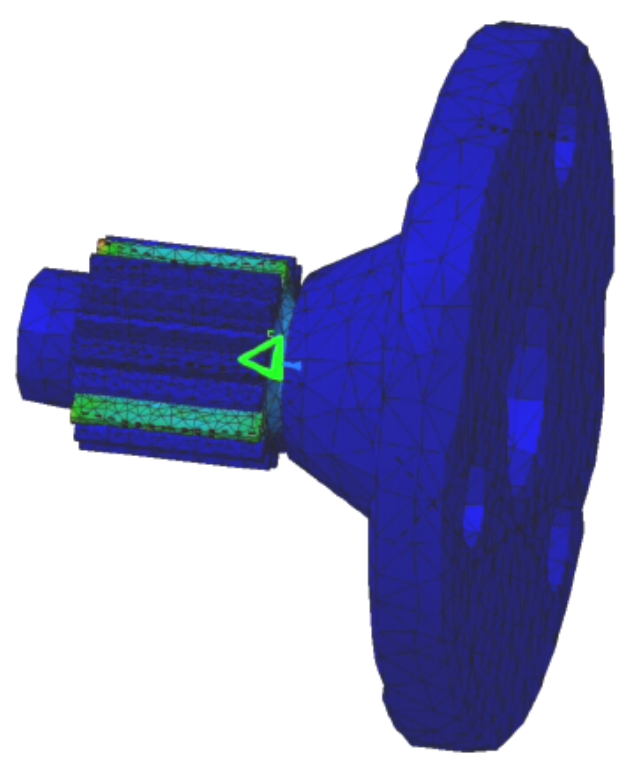

Sl. 2 - Prvi oblik oscilovanja nosača satelita pri $f_{1}=442 \mathrm{~Hz}$ 


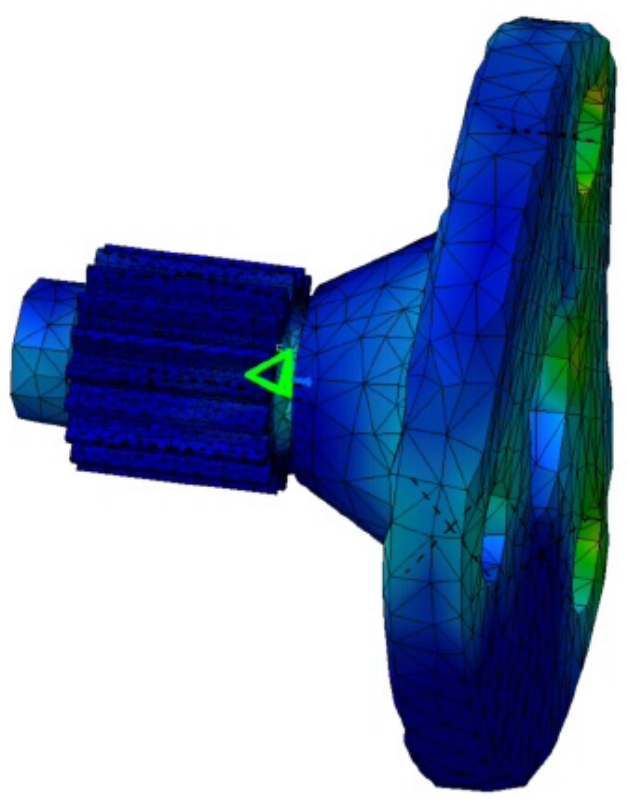

Sl. 3 - Treći oblik oscilovanja nosača satelita pri $f_{3}=6853 \mathrm{~Hz}$

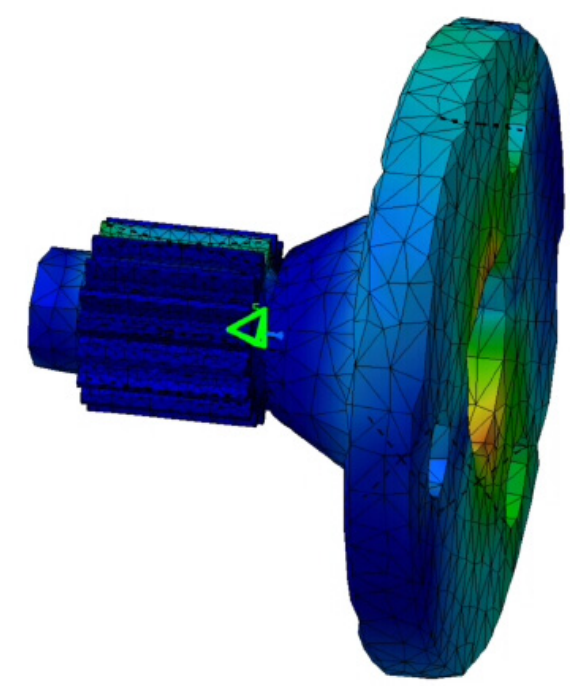

Sl. 4 - Šesti oblik oscilovanja nosača satelita pri $f_{6}=8691 \mathrm{~Hz}$

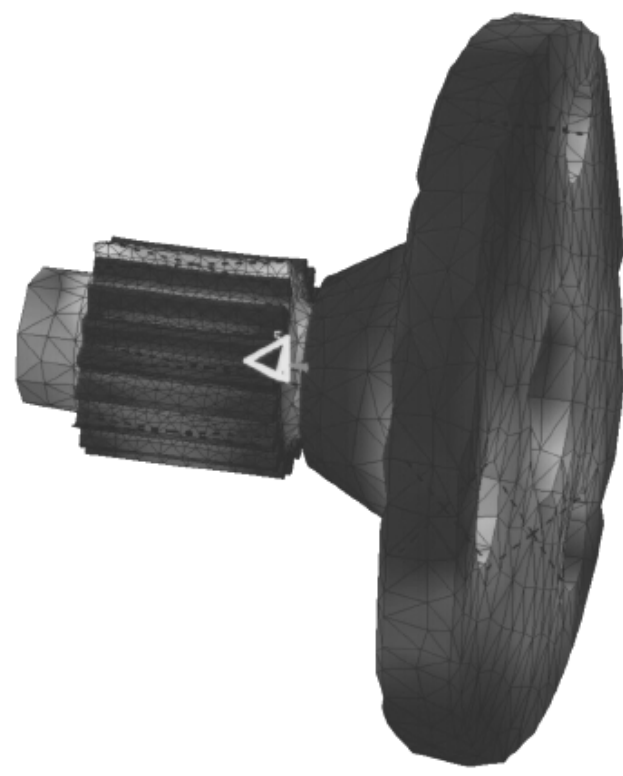

Sl. 5 - Deseti oblik oscilovanja nosača satelita prif $f_{10}=13707 \mathrm{~Hz}$

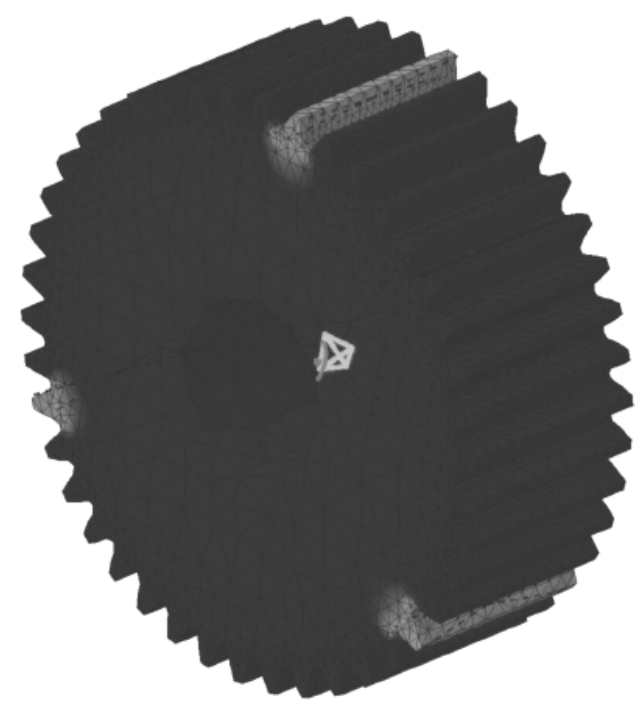

Sl. 6-Prvi oblik oscilovanja satelita pri $f_{l}=671 \mathrm{~Hz}$ 
$\mathrm{Na}$ osnovu pobudnog spektra frekvencija izračunat je neki konačan broj sopstvenih učestanosti satelita, a za analizu je uzeto prvih deset, čijim uspostavljanjem se bitnije utiče na dinamičko ponašanje sistema ili tela. Sopstvene učestanosti prikazane su u tabeli 2.

Tabela 2

\begin{tabular}{|c|c|c|c|c|c|c|c|c|c|c|}
\hline & $\begin{array}{c}\text { Mod } \\
1\end{array}$ & $\begin{array}{c}\text { Mod } \\
2\end{array}$ & $\begin{array}{c}\text { Mod } \\
3\end{array}$ & $\begin{array}{c}\text { Mod } \\
4\end{array}$ & $\begin{array}{c}\text { Mod } \\
5\end{array}$ & $\begin{array}{c}\text { Mod } \\
6\end{array}$ & $\begin{array}{c}\text { Mod } \\
7\end{array}$ & $\begin{array}{c}\text { Mod } \\
8\end{array}$ & $\begin{array}{c}\text { Mod } \\
9\end{array}$ & $\begin{array}{c}\text { Mod } \\
10\end{array}$ \\
\hline$\Omega / \mathrm{Hz}$ & 671 & 4489 & 11758 & 12194 & 15121 & 15184 & 16151 & 16184 & 16912 & 17000 \\
\hline
\end{tabular}

$\mathrm{Na}$ slikama 6 do 9 prikazani su oblici oscilovanja satelita za pripadajuće im frekvencije.

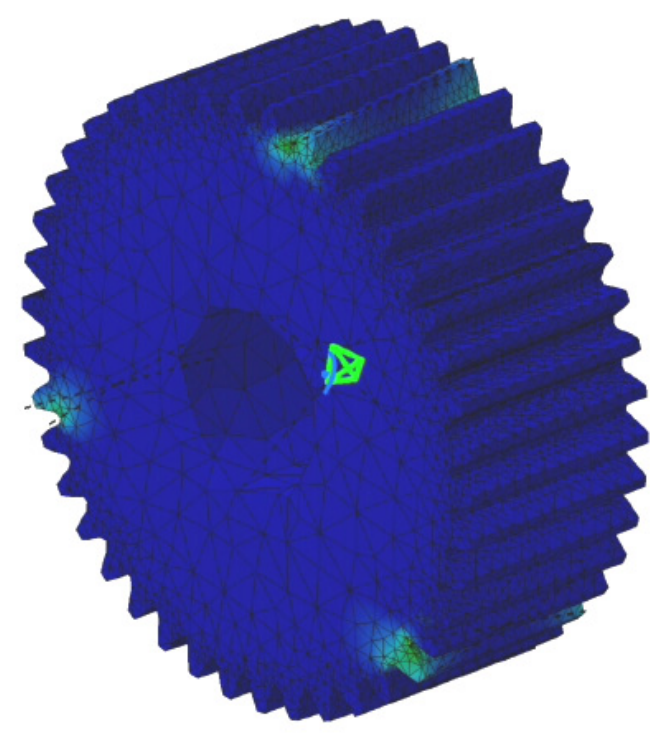

Sl. 7 - Treći oblik oscilovanja satelita pri $f_{3}=11758 \mathrm{~Hz}$

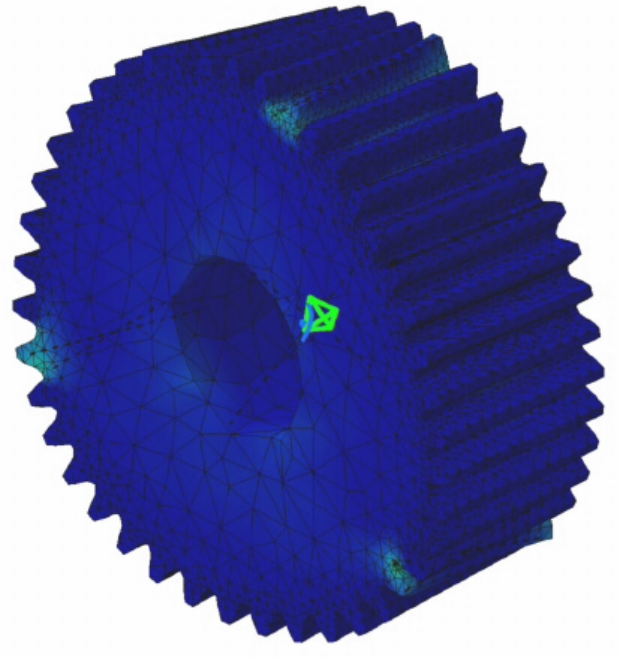

Sl. 8 - Šesti oblik oscilovanja satelita pri $f_{6}=15184 \mathrm{~Hz}$

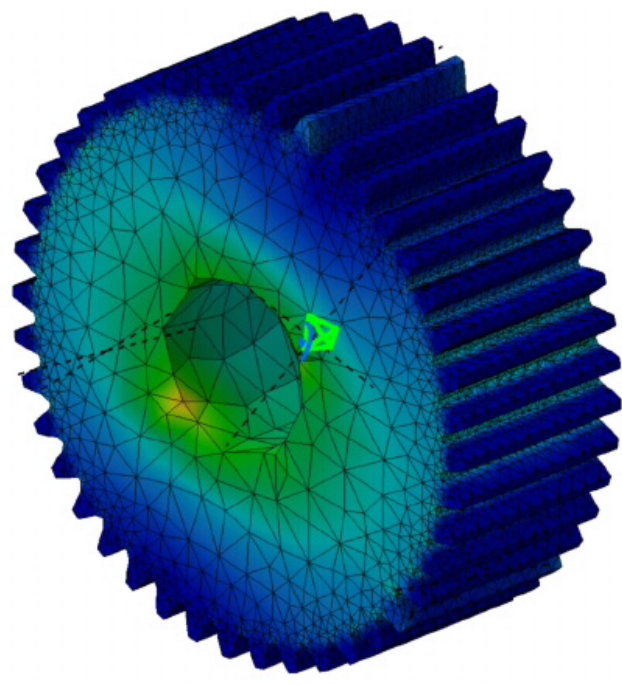

Sl. 9 -Deseti oblik oscilovanja satelita pri $f_{10}=17000 \mathrm{~Hz}$

$\mathrm{Na}$ osnovu pobudnog spektra frekvencija izračunat je neki konačan broj sopstvenih učestanosti venačnog zupčanika, a za analizu je uzeto prvih deset, čijim uspostavljanjem se bitnije utiče na dinamičko ponašanje sistema ili tela. Sopstvene učestanosti prikazane su u tabeli 3. 
Tabela 3

Mod Mod Mod Mod Mod Mod Mod Mod Mod Mod \begin{tabular}{|c|c|c|c|c|c|c|c|c|c|}
\hline 1 & 2 & 3 & 4 & 5 & 6 & 7 & 8 & 9 & 10
\end{tabular} \begin{tabular}{l|l|l|l|l|l|l|l|l|l|l|}
$\Omega / \mathrm{Hz}$ & 1470 & 1512 & 2743 & 2864 & 3162 & 3463 & 3648 & 3724 & 4233 & 4482
\end{tabular}

Oblici oscilovanja venačnog zupčanika za pripadajuće im frekvencije prikazani su na slikama 10 do 13 .

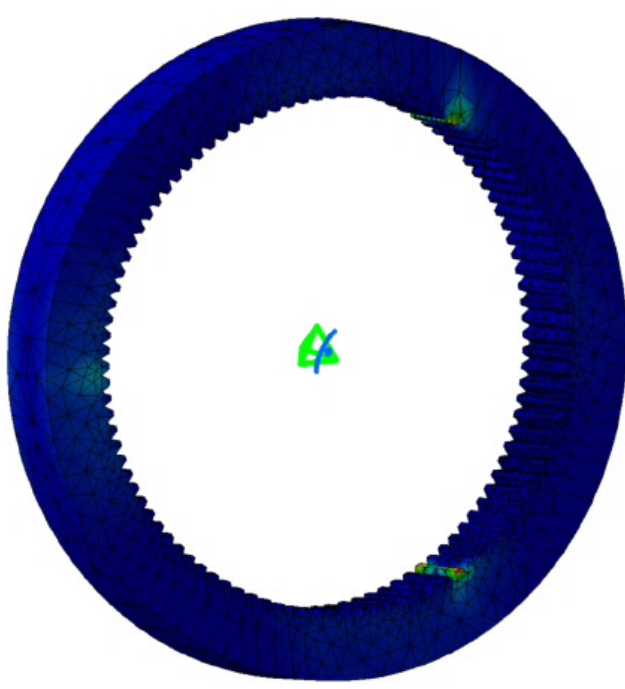

Sl. 10 - Prvi oblik oscilovanja venčanika pri $f_{1}=1470 \mathrm{~Hz}$

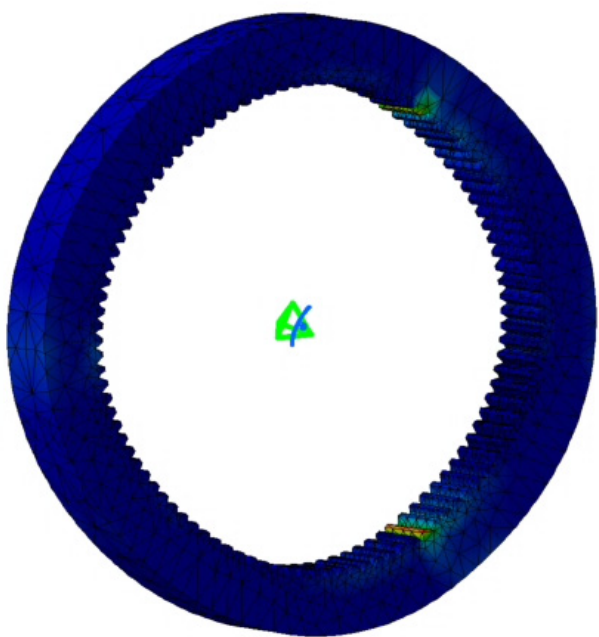

Sl. 11 - Treći oblik oscilovanja venčanika pri $f_{3}=2743 \mathrm{~Hz}$

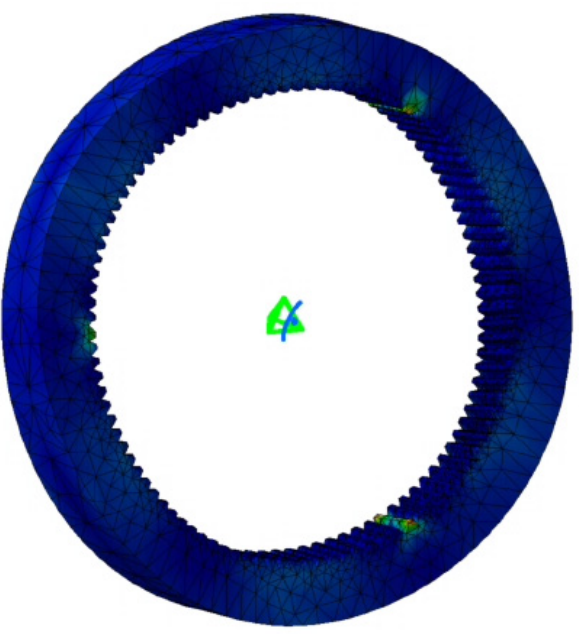

Sl. 12 - Šesti oblik oscilovanja venčanika pri $f_{6}=3463 \mathrm{~Hz}$

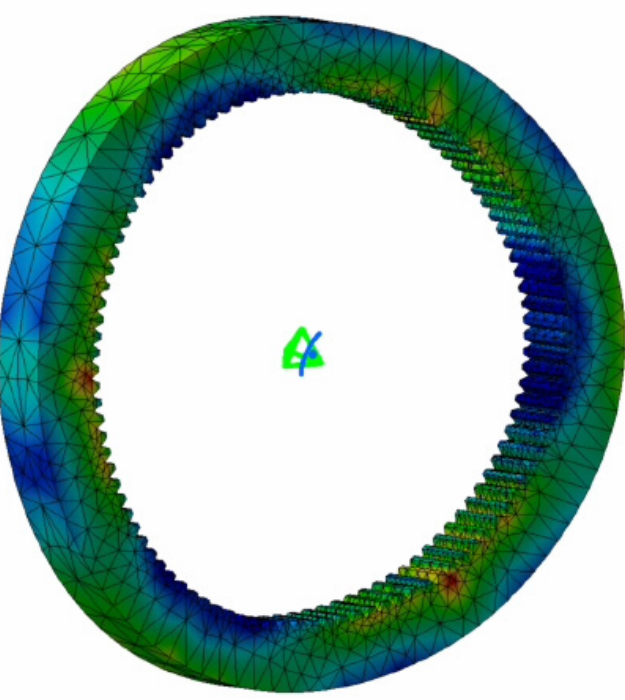

Sl. 13 - Deseti oblik oscilovanja venčanika pri $f_{10}=4482 \mathrm{~Hz}$

\section{Zaključak}

Na osnovu prikazanih modalnih oblika delova planetarnog seta može se zaključiti:

- pri određenoj frekvenciji struktura se raspodeli na određeni broj zona koje osciluju svaka za sebe istom frekvencijom; 
- broj modalnih zona povećava se sa povećanjem sopstvene učestanosti;

- na modalnim oblicima oscilovanja za pripadajuće im frekvencije jasno su istaknute zone sa povećanim naponima i deformacijama u kojima može doći do oštećenja strukture;

- primetna je bliskost prve i druge sopstvene učestanosti venačnog zupčanika, posmatranog seta, što bi promenom nekog od konstruktivnih elemenata trebalo da se izbegne.

\section{Literatura:}

[1] Colbourne, J. R.: The geometric design of internal gear pairs, AGMA Technical Paper, 87 FTM2, 1987.

[2] Parker, R. G., Agashe, V., Vijayakar, S. M.: Dinamic response of a planetary gear system using a finite - element contact mechanics model, ASME, Journal of Mechanical Design, Vol. 122, pp. 304-311, 2000.

[3] Kahraman, A.: Natural Modes of Planetary Gear Trains, Journal of Sound and Vibration, Vol. 173(1), pp. 125-130, 1994.

[4] Kahraman, A.: Free Torsional Vibration Characteristics of Compound Planetary Gear Sets, Mechanism and Machine Theory, Vol. 36, pp. 953-971, 2001.

[5] Sekulović, M.: Metod konačnih elemenata, Građevinska knjiga, Beograd, 1984. 